\title{
Preferential magma extraction from K- and metal-enriched source regions in the crust
}

\author{
Andrew G. Tomkins • Roberto F. Weinberg • \\ Chris R. M. McFarlane
}

Received: 18 September 2007 / Accepted: 28 July 2008

(C) Springer-Verlag 2008

\begin{abstract}
We compare melting of potassic alteration zones in metamorphosed gold deposits with that of unaltered rocks of the same protolith to examine their relative contributions to crust-derived magmas and to investigate the implications for ore genesis. Potassic hydrothermal alteration, at the crustal levels where orogenic gold deposits form, stabilizes a higher proportion of muscovite and biotite than is possible in unaltered rocks at high metamorphic grades. Because these micas contain water, they control the melt fraction generated through dehydration melting in that a greater proportion of micas permits more extensive melting. Orogenic gold deposits, in which mineralization is typically encapsulated by potassic alteration, form at deep-enough crustal levels to survive repeated tectonic activity, which can lead to their being metamorphosed. In the vicinity of this metamorphosed gold mineralization, the greatest proportion of felsic melt is generated in the more metal- and sulfur-rich rocks because of the associated potassic alteration. Ore minerals dissolve and are physically incorporated into the resulting felsic melt, which thereby becomes metal- and sulfur-enriched. Since melt fraction is the dominant control on strain partitioning and melt mobilization, increased melting in K-altered mineralized rocks implies that these sites will be the first to experience melt escape and will continue to be the focus of melt escape
\end{abstract}

Editorial handling: Rolf Romer

A. G. Tomkins $(\bowtie) \cdot$ R. F. Weinberg

School of Geosciences, Monash University,

PO Box 28E, Victoria, Australia 3800

e-mail: andy.tomkins@sci.monash.edu.au

C. R. M. McFarlane

Research School of Earth Sciences,

Australian National University,

A.C.T., Australia 0200 during ongoing metamorphism. This strain partitioning promotes shear zone development, and once shearing is localized to $\mathrm{K}$-altered mineralized domains, it may attract external magma, allowing extension and linking with nearby active shear zones. In this way, mineralized zones may connect to a regional network of magma transfer, allowing metal enrichment of migrating magmas. Terrains that underwent widespread $\mathrm{K}$ alteration associated with mid-crustal gold enrichment are likely, when metamorphosed, to produce significant volumes of reduced, relatively metal- and sulfur-enriched felsic magma. The ages and relative tectonic preservation potential of different $\mathrm{K}$ alteration-associated ore types implies that $\mathrm{Au}, \mathrm{Ag}, \mathrm{As}, \mathrm{Sb}$, $\mathrm{Bi}, \mathrm{Te}$, and $\mathrm{W}$ may be recycled within the crust through this mechanism, whereas $\mathrm{Cu}$ and Mo are unlikely to be recycled and require mantle sourcing to form new intrusion-related ores. Silicate melt derived from preexisting zones of gold enrichment in the lower crust may contribute significantly to the metal budget of intrusion-related gold systems, and possibly some gold-rich porphyry deposits.

Keywords Ore genesis - Source - Anatexis . Granite metallogeny $\cdot$ Intrusion-related gold

\section{Introduction}

Felsic magma-related ore deposits are Earth's largest source of copper, molybdenum, tin, tungsten, and a major source of gold. At the broadest scale, some continental-scale regions contain many felsic magma-related ore deposits, whereas others are relatively barren. Even within rich provinces, a few intrusions are associated with mineralization, and the majority are barren. It is likely that there are several explanations for these observations, and one of 
these may be variability in the magma source. Yet, there have been a few studies of processes that affect metal distribution in magma source regions.

Various suggestions have been offered for the source of metals in felsic magma-related ore deposits. Some suggest that in arc regions, metal is derived from subducted oceanic slab or overlying metasomatized mantle wedge (Mungall 2002; Sillitoe 1997), remnant metallogenic heterogeneities in the mantle (Sillitoe 1972), adjacent intruded crust (Krauskopf 1967), or from the lower crust during anatexis (Hedenquist and Lowenstern 1994; Tomkins and Mavrogenes 2003). Intrusion-related gold systems form distally to arcs and are typically associated with reduced granitic magmas thought to be largely derived from partial melting of crustal rocks (Lang and Baker 2001), casting into question the absolute need for oceanic slab or mantle involvement. Even within arcs, evolution of ore-producing magmas may involve mixing between mantle- and crust-derived magmas (Richards 2003). It is therefore crucial to understand processes that influence the metal content of these crust-derived magmas.

This paper investigates differences in the proportions of magma produced through dehydration melting of rocks previously subjected to potassic hydrothermal alteration compared to unaltered rocks of the same protolith. Many of these altered rocks are metal-enriched, and the results therefore have implications for the metal content of crustderived melts. Pseudosections calculated with the thermodynamic program THERMOCALC are used to model differences in melt production for both a pristine unmetamorphosed gold deposit, with associated $\mathrm{K}$ alteration, and a gold deposit metamorphosed at granulite facies conditions, where differences in melt production can be observed. Linking this information with an understanding of melt extraction dynamics allows an assessment of the role of crust-derived magmas in generation of intrusion-related ore systems in the upper crust.

\section{K-metasomatism and associated metal enrichment}

There are many different environments where rocks can be subject to addition of potassium via hydrothermal fluids. Most types of ore deposits associated with felsic magmas have an attendant K-alteration signature, including (1) greisen-hosted $\mathrm{Sn}-\mathrm{W}-\mathrm{Mo}$ deposits, (2) porphyry $\mathrm{Cu} \pm \mathrm{Au} \pm$ Mo deposits, (3) IOCG deposits, and (4) many intrusionrelated Au systems. Orogenic gold deposits are also almost invariably characterized by potassic alteration and formed periodically throughout Earth history, mainly during the Archean and Phanerozoic (Groves et al. 2005).

Other processes unrelated to metal enrichment can also lead to formation of zones of $\mathrm{K}$ enrichment within the crust. Diagenesis can, in some cases, promote localized $\mathrm{K}$ enrichment, and weathering can also lead to localized enrichment in potassic clays. Deeper within the crust, fault zones, as well as broad shear zones, are the focus of fluid flow, and this allows some of these regions to become Kenriched. The Broken Hill Block in western New South Wales contains examples of this shear zone K-enrichment. At this locality, there are many broad Delamerian aged (490-514 Ma; Rutherford et al. 2006) shear zones with lithologies that are significantly more muscovite- and biotite-rich than their unaffected protoliths. These processes create some of the natural variability in the fertility of rocks that is a characteristic of any broad crustal region.

Because most felsic magma-associated ore deposit types form at shallow crustal levels in zones of crustal thickening and high topographic relief, they have a high probability of being removed by erosion shortly after they form. For example, most of the currently mined giant porphyry $\mathrm{Cu}$ deposits are $<50 \mathrm{My}$ old and were actively being eroded when found. In contrast, the numerous Archean orogenic gold deposits were able to survive the weathering process for much longer because they formed at deeper crustal levels. Thus, orogenic gold deposits have significantly higher tectonic preservation potential than porphyry $\mathrm{Cu}$ deposits. Since some intrusion-related gold systems and intrusion-associated $\mathrm{Sn}-\mathrm{W}$ deposits form at slightly deeper crustal levels than porphyry $\mathrm{Cu}$ deposits (e.g., Baker 2002), they have higher preservation potentials. However, most of these deposits are Phanerozoic in age (Seedorf et al. 2005; Cerny et al. 2005; Lang and Baker 2001) and, thus, have not had time to form, stabilize, and then be tectonically emplaced into a position in which they can be metamorphosed. We have therefore focused on metamorphism of orogenic $\mathrm{Au}$ deposits because these have a greater probability of being preserved and later metamorphosed than other deposit types.

Orogenic gold deposits form through migration of metamorphic fluids through shear zones and are typically associated with second- or third-order faults connected to large crustal-scale shear zones (Groves et al. 1998). Ore minerals found within these deposits are, in addition to gold, dominated by pyrite, pyrrhotite, and arsenopyrite, but minor and varying amounts of tellurides, bismuthinides, chalcopyrite, stibnite, sphalerite, galena, and scheelite can be present. Groves et al. (1998) indicate that most orogenic gold deposits are characterized by addition of $\mathrm{S}, \mathrm{K}, \mathrm{H}_{2} \mathrm{O}$, and $\mathrm{CO}_{2}$, and in some, $\mathrm{Na}, \mathrm{Ca}$, and LILE, to host rocks ranging from mafic rocks (most Archean deposits) to pelitic and psammitic turbidites (most post-Archean deposits). Potassic alteration in these deposits typically results in formation of new muscovite and biotite, depending partly on the bulk composition of the altered protolith and the degree of alteration (e.g., White et al. 2003), although Kfeldspar is found in some deposits thought to have formed 
under amphibolite facies conditions (Ridley et al. 2000). The majority orogenic gold deposits formed at $300 \pm 50^{\circ} \mathrm{C}$ and 1-3 kbar, although some formed at conditions up to $450-600^{\circ} \mathrm{C}$ and 3-5 kbar (Groves et al. 1998).

Retention of water within metasomatized rocks will be shown below to be a critical control on the proportion of melt generated during subsequent metamorphism. Water is retained within micas, clays, and chlorite, so the amount of $\mathrm{K}$ added partly controls the proportion of $\mathrm{H}_{2} \mathrm{O}$ retained within the rock. Note that potassic alteration that is dominated by formation of K-feldspar rather than muscovite does not favor retention of $\mathrm{H}_{2} \mathrm{O}$. Most added cations are preserved within the altered volume during subsequent metamorphism up to mid-amphibolite facies conditions, as biotite, muscovite, and feldspars are stable at these conditions. Breakdown of clay-bearing alteration assemblages in the greenschist facies will lead to $\mathrm{H}_{2} \mathrm{O}$ loss, although some will be retained within newly formed phyllosilicate minerals. In chlorite- and carbonate-bearing rocks, some $\mathrm{H}_{2} \mathrm{O}$ may be lost upon conversion of chlorite to hornblende, biotite, or other $\mathrm{Fe}-\mathrm{Mg}$ silicates at the greenschist-amphibolite facies transition, and $\mathrm{CO}_{2}$ is lost through destabilization of carbonates in the lower amphibolite facies (Elmer et al. 2006).

In our modeling below, we assume complete destruction of the carbonate assemblage and that all $\mathrm{H}_{2} \mathrm{O}$ is lost except that necessary to stabilize the proportion of biotite and muscovite required by the $\mathrm{K}_{2} \mathrm{O}$ content of the bulk rock. This assumption is consistent with the general understanding among metamorphic petrologists that upper amphibolite to granulite facies rocks are typically dry (e.g., Spear 1993).

\section{Simulated metamorphism of a gold deposit}

It has been recognized for some time that pelitic to quartzofelspathic rocks produce more melt than intermediate to mafic rocks and that rocks that have undergone weathering, or any other hydration process, will produce more melt than anhydrous rocks of otherwise same bulk composition (e.g., Clemens and Vielzeuf 1987; Thompson 1996). However, this concept has not hitherto been applied to partial melting of mineralized rocks. In the following, an orogenic $\mathrm{Au}$ deposit from the Victorian goldfields is subjected to simulated metamorphism using the thermodynamic modeling program THERMOCALC (Holland and Powell 1998) to investigate the differences in fraction of melt that would be generated within altered mineralized rock compared to unaltered rock if the deposit was metamorphosed.

The Victorian Goldfields, in southeast Australia, have produced over 2,500 $\mathrm{t}$ of $\mathrm{Au}$ (Wilde et al. 2004) from numerous small, rich deposits hosted in pelitic to psammitic turbidites spread over a large region. The Wattle Gully deposit (Fig. 1) selected for this study is a typical example (Cox et al. 1995). Globally, the majority of crust-derived felsic magma is generated through melting of sedimentary rocks, similar to the turbidites at Wattle Gully, which contribute to peraluminous granitic magmas (Clemens and Vielzeuf 1987).

Bierlein et al. (1998) have published a detailed account of the alteration at Wattle Gully (including whole rock geochemistry and mineralogical descriptions) and the Victorian Goldfields in general, and the following is summarized from this work. The turbidites at Wattle Gully were subject to lowermost greenschist facies metamorphism, and the gold therein is thought to have been introduced by metamorphic fluids generated during the same tectonic cycle. Unaltered rocks contain metamorphic micas, chlorite, and carbonates. Alteration at Wattle Gully is similar to that found in gold deposits regionally in that the altered rocks are only subtly different to the protolith. The most obvious sign of alteration is the sulfide assemblage of disseminated arsenopyrite and pyrite, with minor sphalerite, galena, chalcopyrite, pyrrhotite, and gold also being observed. These ore minerals are associated with mild carbonate, sericite, and chlorite alteration. The subtle sericite alteration is characterized by low modal abundance of fine-grained K-mica laths developed on cleavage planes and also large blades overgrowing the main structural foliation. Chemical components added to the rock through alteration at Wattle Gully include $\mathrm{K}, \mathrm{H}_{2} \mathrm{O}, \mathrm{CO}_{2}, \mathrm{~S}$, As, and $\mathrm{Au}$. The size of the alteration halo is poorly constrained due to its subtle nature. However, the comparatively easily observable carbonate spotting extends to $30-50 \mathrm{~m}$ from the quartz reefs. Arsenic reaches background concentrations at distances as far as $100 \mathrm{~m}$ laterally away from the veins. Tourmalinization and albitization is also recognized at some deposits in the region.

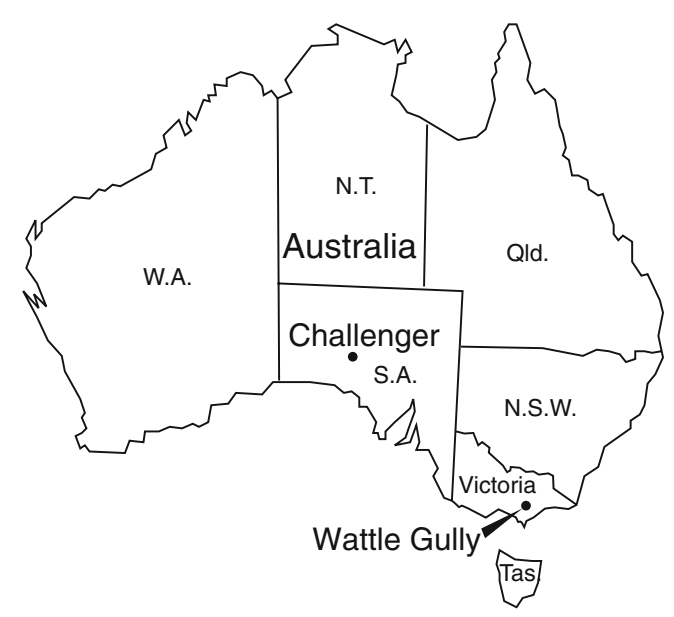

Fig. 1 Location of the Wattle Gully and Challenger gold deposits 
Pressure-temperature pseudosections in the system $\mathrm{Na}_{2} \mathrm{O}$ $\mathrm{CaO}-\mathrm{K}_{2} \mathrm{O}-\mathrm{FeO}-\mathrm{MgO}-\mathrm{Al}_{2} \mathrm{O}_{3}-\mathrm{SiO}_{2}-\mathrm{H}_{2} \mathrm{O}$ (NCKFMASH; White et al. 2001) for two bulk compositions (Fig. 2 caption) from Wattle Gully were constructed and contoured for melt
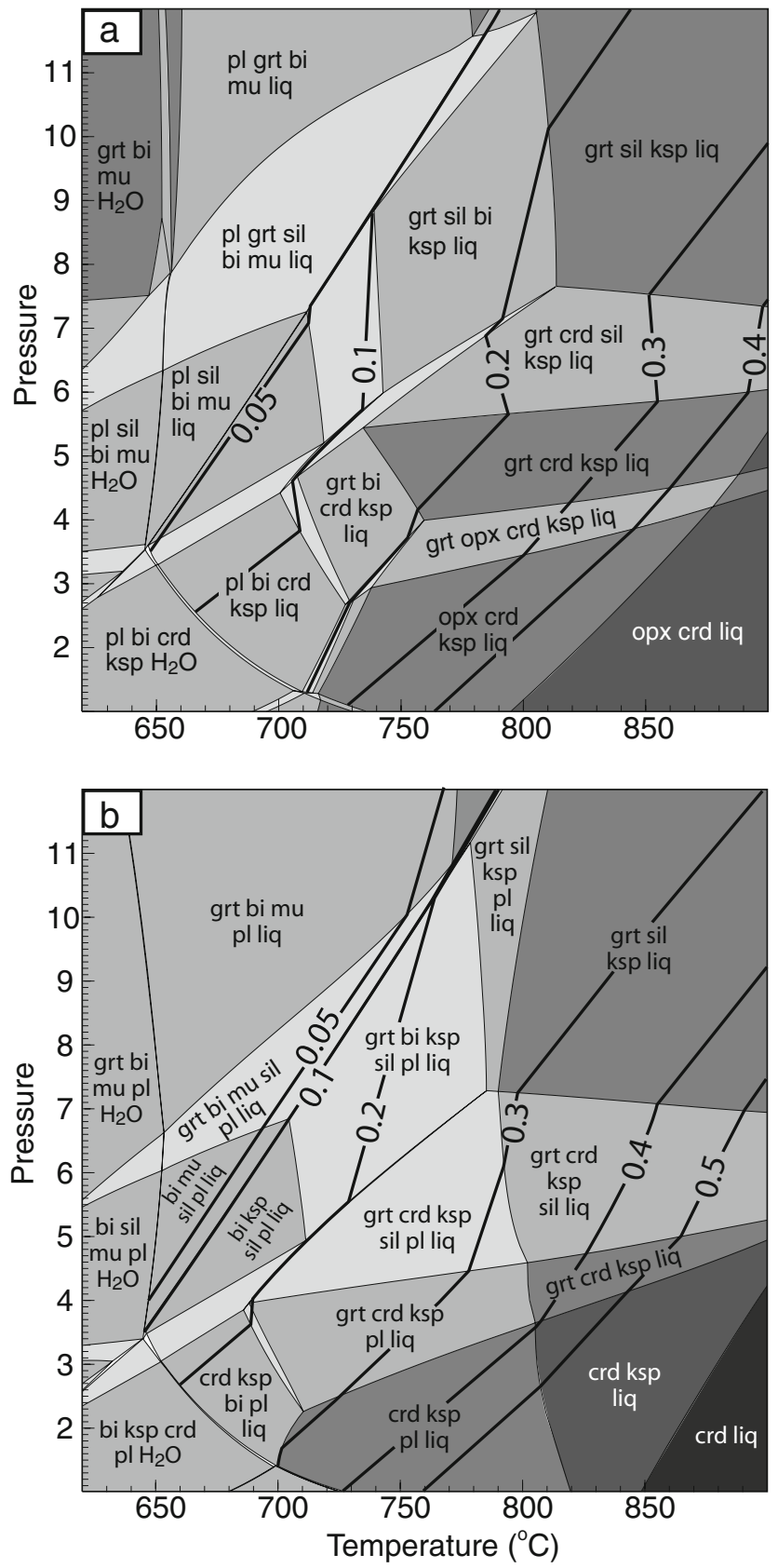

Fig. $2 P-T$ pseudosections calculated in the system NCKFMASH for bulk compositions (data from Bierlein et al. 1998) in the vicinity of the Wattle Gully gold deposit, contoured for melt fraction. a Distal unaltered turbidite, bulk composition $(\mathrm{mol} \%): \mathrm{H}_{2} \mathrm{O}=4.73, \mathrm{SiO}_{2}=$ 73.65, $\mathrm{Al}_{2} \mathrm{O}_{3}=9.65, \mathrm{CaO}=0.08, \mathrm{MgO}=3.80, \mathrm{FeO}=4.84, \mathrm{~K}_{2} \mathrm{O}=2.13$, $\mathrm{Na}_{2} \mathrm{O}=1.10$. b Proximal mineralized, metasomatized turbidite, bulk composition (mol\%): $\mathrm{H}_{2} \mathrm{O}=5.84, \mathrm{SiO}_{2}=72.19, \mathrm{Al}_{2} \mathrm{O}_{3}=10.88, \mathrm{CaO}=$ $0.24, \mathrm{MgO}=2.17, \mathrm{FeO}=3.26, \mathrm{~K}_{2} \mathrm{O}=2.46, \mathrm{Na}_{2} \mathrm{O}=2.97 . \mathrm{H}_{2} \mathrm{O}$ in both cases is the minimum needed to saturate the micas immediately subsolidus at $7.45 \mathrm{kbar}$ fraction (from data published by Bierlein et al. 1998), one for unaltered shale $210 \mathrm{~m}$ from ore, and one for altered shale from within the ore zone.

Comparison of these two pseudosections (Fig. 2a and b) illustrates that even mild potassic alteration can significantly influence the melt fraction generated during subsequent metamorphism. They show that under some pressuretemperature conditions, more than double the amount of melt is generated in the metasomatized and mineralized rock.

\section{Variable melting at the Challenger gold deposit: metamorphosed at granulite facies conditions}

Pressure-temperature pseudosections were also generated for the Challenger $\mathrm{Au}$ deposit (located in the northwest Gawler Craton, South Australia; Fig. 1), which was metamorphosed at granulite facies conditions $\left(\sim 850^{\circ} \mathrm{C}, 7.5 \mathrm{kbar}\right.$; Tomkins and Mavrogenes 2002). The host rocks at Challenger are a monotonous sequence of graphitic intermediate to felsic metavolcaniclastics with little variation in bulk composition (McFarlane et al. 2007). These rocks underwent variable partial melting over the period 2,443 to 2,428 Ma (McFarlane 2006; Tomkins et al. 2004a, b) to produce a stromatic migmatite with peritectic garnet, cordierite, and orthopyroxene (Tomkins and Mavrogenes 2002). However, some quartz-dominated leucocratic veins within the ore zone are likely to be metamorphosed quartz veins, originally formed during the mineralization event (McFarlane et al. 2007). Ore minerals found at Challenger include gold, löllingite, arsenopyrite, pyrrhotite, native bismuth, chalcopyrite, pentlandite and rare maldonite, sphalerite, molybdenite, and bismuthinite.

Based on the relative abundance of leucosomes and refractory peritectic minerals, observation suggests that unaltered rocks underwent minor partial melting (fewer leucosomes and peritectic minerals; Fig. 3a), whereas mineralized rocks experienced more extensive melting (abundant stromatic leucosomes and peritectic minerals; Fig. 3b). Evidence of melt migration exists within mineralized domains: restitic assemblages that are anomalously rich in peritectic minerals indicate areas of melt loss, and structurally dilatant zones (centimeter to meter in size) filled with quartz, K-feldspar, and plagioclase represent regions of melt accumulation.

Pressure-temperature pseudosections were again constructed in the system NCKFMASH, using bulk compositions (Fig. 4 caption) for the Challenger mineralized gneiss and unmineralized gneiss. Calculated bulk compositions were obtained by correcting whole-rock analyses for melt loss. This correction was done by treating the REE as immobile components during metasomatism and adding a 


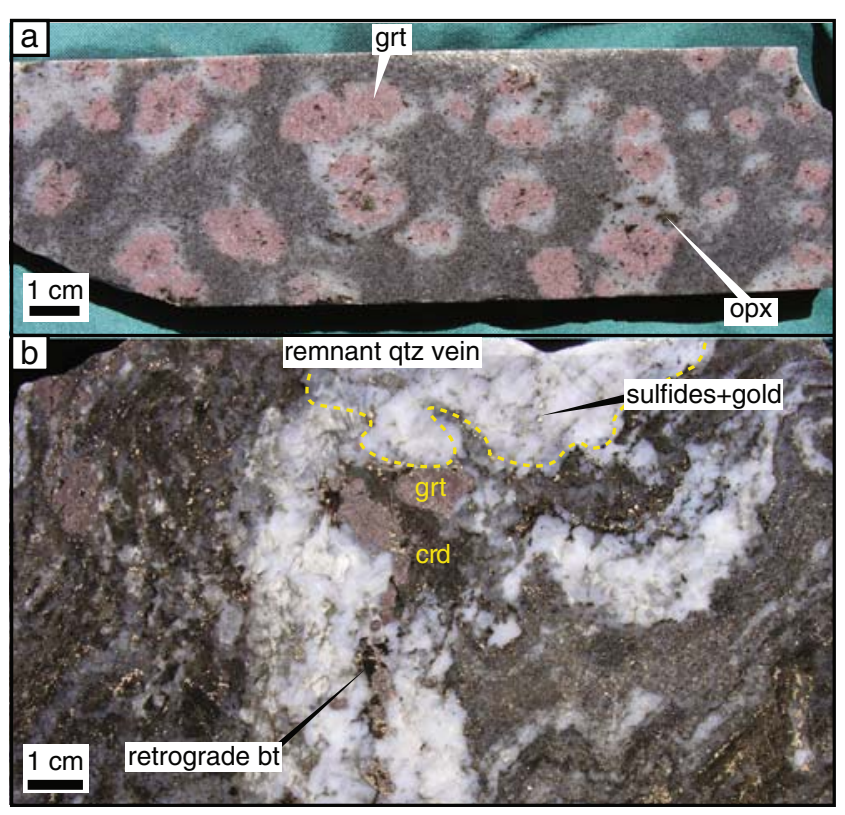

Fig. 3 Unmineralized and mineralized gneisses from Challenger. a Leucosome-poor unmineralized garnet-orthopyroxene gneiss. b Leucosome-rich gold-bearing garnet-cordierite migmatite. Coarsegrained biotite at garnet margins indicates retrograde reaction between melt and peritectic garnet. Many of the premetamorphic quartz veins at Challenger are partially consumed by locally quartz-undersaturated melts (cumulate quartz-absent, garnet-cordierite-spinel-corundumbearing assemblages indicate quartz undersaturation), yet retain gold and sulfides within remnant domains such as that pictured. Abundant sulfide grains remain in regions from which melt has been extracted (darker cordierite-rich region to the left), although some are also within the leucosomes

sufficient volume fraction of granitic composition back into the restitic gneiss to reproduce the average REE composition of distal gneisses. Addition of between 30 and 40 vol.\% granite was necessary, consistent with other studies (White and Powell 2002) that suggest $>30 \%$ melt loss is required to preserve anhydrous granulite assemblages. A weakness of this approach is that the latter may also have lost a small degree of melt, which if added would modify the results, making both compositions equally more fertile. The forward modeling on the Wattle Gully deposit was done specifically to accommodate this weakness, to remove any doubt relating to issues of melt loss at Challenger.

An initial set of pseudosections was calculated using the minimum amount of $\mathrm{H}_{2} \mathrm{O}$ needed to saturate the minerals immediately subsolidus at $7 \mathrm{kbar}$. This resulted in significantly different proportions of $\mathrm{H}_{2} \mathrm{O}$ in the mineralized gneiss $(4.97 \%)$ and the unmineralized gneiss $(3.40 \%)$, reflecting the difference in mica content prior to melting. Under these starting conditions, the activity of water $\left(\mathrm{aH}_{2} \mathrm{O}\right)$ is 1 prior to melting. However, Challenger contains graphite, and reaction between this and $\mathrm{H}_{2} \mathrm{O}$ reduces $\mathrm{aH}_{2} \mathrm{O}$, shifting the initial melting reactions to higher temperatures (Clemens and Vielzeuf 1987). To accommodate this phenomenon a second set of $P-T$ pseudosections, using the same $\mathrm{H}_{2} \mathrm{O}$ contents and bulk compositions, was constructed. This was done using the thermodynamic program PerpleX (Connolly and Cesare 1993) to calculate
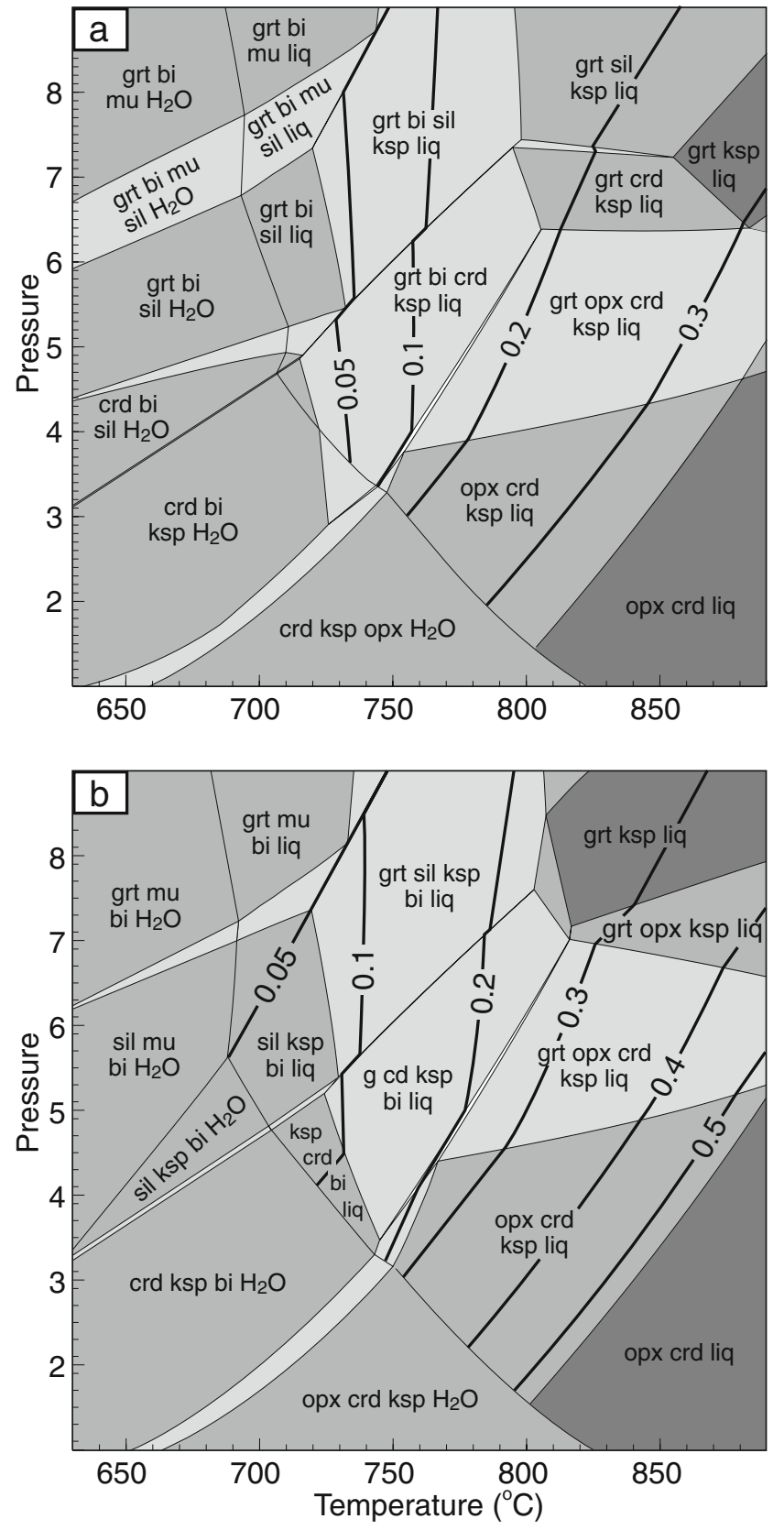

Fig. $4 P-T$ pseudosections calculated in the system NCKFMASH for bulk compositions in the vicinity of the Challenger gold deposit, taking into consideration the effect of graphite in lowering $\mathrm{aH}_{2} \mathrm{O}$, on the stability of subsolidus and solidus reactions and contoured for melt fraction. a Unaltered gneiss, bulk composition (mol\%): $\mathrm{H}_{2} \mathrm{O}=3.4, \mathrm{SiO}_{2}=$ 71.29, $\mathrm{Al}_{2} \mathrm{O} 3=9.25, \mathrm{CaO}=1.89, \mathrm{MgO}=3.41, \mathrm{FeO}=4.61, \mathrm{~K}_{2} \mathrm{O}=1.61$, $\mathrm{Na}_{2} \mathrm{O}=2.92$. b Mineralized, metasomatized gneiss, bulk composition (mol\%): $\mathrm{H}_{2} \mathrm{O}=4.97, \mathrm{SiO}_{2}=69.21, \mathrm{Al}_{2} \mathrm{O}_{3}=10.13, \mathrm{CaO}=1.80, \mathrm{MgO}=$ 3.91, $\mathrm{FeO}=4.41, \mathrm{~K}_{2} \mathrm{O}=2.21, \mathrm{Na}_{2} \mathrm{O}=3.36 . \mathrm{H}_{2} \mathrm{O}$ in both cases is the minimum needed to saturate the micas immediately subsolidus at $7 \mathrm{kbar}$ 
values for maximum $X \mathrm{H}_{2} \mathrm{O}$ at the relevant range of temperatures and pressures for a fluid in the presence of graphite. These $X_{2} \mathrm{O}$ values were then converted to $\mathrm{aH}_{2} \mathrm{O}$ and used in conjunction with THERMOCALC to estimate the shift of the sub-solidus and solidus reactions.

The resulting $P-T$ pseudosections (Fig. 4a and b) indicate that at moderate pressures, muscovite disappears prior to melting in unmineralized gneiss, but not in mineralized gneiss, and that for a wide range of $P-T$ conditions, the melt fraction is more than double that for unmineralized gneiss. The pseudosections, therefore, match the rocks well, with higher melt fraction in the mineralized gneiss and similar peak metamorphic mineral assemblage (orthopyroxene-garnet-cordierite). This difference is related directly to addition of $\mathrm{K}$ and $\mathrm{H}_{2} \mathrm{O}$ in the mineralized domains prior to metamorphism, which would have produced a more muscovite-rich and, thus, more $\mathrm{H}_{2} \mathrm{O}$-rich, protolith. In the mineralized gneiss, there would have been more melt produced through muscovite melting, together with more sillimanite production during muscovite breakdown. Sillimanite is the limiting reactant in the garnetproducing melting reaction in both gneisses (as evidenced by preservation of quartz, biotite, and plagioclase, and complete removal of sillimanite), so, again there would have been more melting through this reaction in the mineralized gneiss.

There are, however, some limitations inherent in using this technique. Because the system NCKFMASH does not take into consideration the stabilizing effect of $\mathrm{Ti}$ in $\mathrm{Bt}$, the Bt-breakdown reactions may, in reality, shift significantly towards higher temperatures (White et al. 2002; Challenger biotite has 2.64-6.41 wt.\% $\mathrm{TiO}_{2}$ ). Furthermore, the pseudosections represent closed systems and, as such, do not take melt loss into consideration.

\section{$K$ metasomatism of mafic rocks and subsequent metamorphism}

Mafic rocks are a major host of large gold deposits and also an important source of felsic magma in the deep crust (Clemens and Vielzeuf 1987), so the effect of K metasomatism on partial melting of these must be considered. THERMOCALC cannot model partial melting of mafic rocks; however, assemblages preserved within metasomatized mafic rocks at a range of localities provide constraints that permit a qualitative comparison.

Mafic rocks that have not been subject to $\mathrm{K}$ metasomatism typically contain chlorite + plagioclase \pm quartz \pm actinolite at greenschist facies conditions, or hornblende+ plagioclase \pm quartz in the amphibolite facies. In contrast, the central alteration assemblage of orogenic Au deposits in greenschist facies mafic rocks typically contains quartz + pyrite + muscovite + carbonate \pm biotite \pm albite \pm chlorite, with $\mathrm{K}$ addition accommodated within muscovite and biotite at the expense of chlorite (e.g., White et al. 2003). Orogenic gold deposits hosted by amphibolite are instead typified by biotite- and quartz-rich alteration assemblages at the expense of hornblende (Ridley et al. 2000).

During metamorphism at granulite facies conditions, dehydration melting of amphibolites typically proceeds through reactions such as hornblende + plagioclase + quartz $=$ clinopyroxene + garnet + melt (e.g., Hartel and Pattison 1996). In this reaction, the amount of $\mathrm{H}_{2} \mathrm{O}$ produced via hornblende dehydration limits the melt fraction. At high temperature and moderate pressure or greater, muscovite-bearing rocks undergo dehydration melting through reactions such as muscovite + plagioclase + quartz $=$ sillimanite $+\mathrm{K}$-feldspar + melt. This reaction occurs at lower temperature than the hornblende dehydration reaction (e.g., Spear 1993), so among mafic rocks, melting would occur first in zones of muscovite-bearing hydrothermal alteration associated with gold mineralization. Another melting reaction is possible in biotite-bearing amphibolites: biotite + plagioclase + quartz $=$ orthopyroxene $+\mathrm{K}$-feldspar + melt. It has been found, through experiments on a natural assemblage with biotite+hornblende + clinozoisite + plagioclase + quartz, that biotite undergoes dehydration melting followed by melting involving hornblende (Antignano et al. 2001). However, biotite is likely to eventually become more refractory than hornblende as melting progresses, through its sequestration of Ti, which inhibits its propensity to melt (White et al. 2002). Because biotite and muscovite $\left(\sim 4 \% \mathrm{H}_{2} \mathrm{O}\right)$ contain more than double the amount of $\mathrm{H}_{2} \mathrm{O}$ in hornblende $\left(\sim 1.5 \% \mathrm{H}_{2} \mathrm{O}\right)$, the melt fraction generated by dehydration melting of either is significantly more than that generated by the same proportion of hornblende dehydration. Therefore, high temperature metamorphism of mafic rock-hosted gold mineralization is likely to produce a higher melt fraction, earlier, than the unmineralized equivalent.

\section{Discussion}

Effect of melt fraction on melt extraction

Extraction of intergranular melt from partially molten rocks is driven by both buoyancy and deformation, but the latter is critical for efficient melt segregation (Brown 1994). Melt generation and transport are preferentially focused within shear zones because a range of feedback mechanisms localize melting and shearing together (Mancktelow 2002). Rocks with melt are weaker than unmelted rocks and thus localize strain as soon as melting starts (Rosenberg 
and Handy 2005). Similarly, rocks with greater melt fraction are weaker than melt-poor rocks. Melt fraction is, therefore, the dominant control on the strength of the lower crust (Rosenberg and Handy 2005) and dictates, through strain partitioning, the loci of melt extraction during deformation. Furthermore, pressure gradients within shear zones, whether related to a dilational component, specific dilational sites such as jogs (Brown and Solar 1998) or, more generally, internal fracturing (Mancktelow 2006), attract melt into shear zones. Thus, shear zones control magma transfer through the crust (Brown and Solar 1998).

The ability of K-altered mineralized zones to melt early, and to produce higher melt fractions than their immediate surroundings, implies that they are more likely than their surroundings to localize strain. Furthermore, the greater rate of melt production, coupled with other strain weakening processes, implies that these zones will continually partition strain and attract more magma from the surroundings. As the process develops, incipient magma-rich shear zones will grow and link up with other nearby active and melt-rich shear zones, thereby connecting into a network of magma transfer and stress release. In this way, mineralized zones may become part of a larger-scale transfer system that attracts magmas from the surroundings and feeds them into the network, potentially allowing metal enrichment of the traveling magmas and providing natural pathways for magma extraction from the metal-rich source.

Prior to melting, shear zones serve as channel-ways for hydrothermal fluids, and because $\mathrm{K}$ is highly mobile in these fluids, shear zones and their immediate surroundings are in many cases $\mathrm{K}$ - and $\mathrm{H}_{2} \mathrm{O}$-enriched compared to distal rocks. Therefore, the interconnected greenschist and amphibolite facies fault systems that form the pathways for mineralizing fluids related to orogenic gold deposits are likely to be relatively $\mathrm{K}$ - and $\mathrm{H}_{2} \mathrm{O}$-enriched. Like mineralized rocks, preexisting $\mathrm{K}$-enriched, hydrated shear zones are thus likely to have early and relatively high melt production compared to surrounding rocks and are likely to develop into melt-rich shear systems as metamorphism progresses. These melt-rich shear systems are thus able to connect melt-rich mineralized domains into a network of magma-rich shear zones that act as zones of magma transfer to the upper crust.

It should be noted that these arguments only hold true for dehydration melting. Generation of high melt fractions in zones of $\mathrm{K}$ alteration is only effective because $\mathrm{K}$ addition allows formation of a higher proportion of hydrous minerals, which in turn allow more melt production through greater $\mathrm{H}_{2} \mathrm{O}$ liberation during dehydration. This becomes insignificant when a large amount of externally derived $\mathrm{H}_{2} \mathrm{O}$ allows widespread vapor-saturated melting. Vaporabsent conditions are, however, thought to dominate the lower crust (Clemens and Vielzeuf 1987).
Effect of lithological heterogeneity on melt extraction

From the above discussion, it is evident that in an unmineralized heterogeneous package of rocks consisting of pelitic material interspersed with mafic material, which at granulite facies conditions generate high and low melt fractions respectively, the pelitic rocks would be the focus of melt extraction. However, what should be expected from the same package of rocks containing mineralized mafic material: would any melt be extracted from the mineralized domains? Since we cannot model melting in mafic rocks, we cannot answer this question quantitatively. Muscovitic alteration assemblages are observed in extremely altered mafic rocks in gold deposits (at the Golden Mile for example; White et al. 2003), which would generate early melt when metamorphosed, thereby becoming favorable sites for melt extraction. However, low-muscovite, biotitic assemblages are also common in altered mafic rocks, and these must be considered. Our observations, and those of others (e.g., Garrido et al. 2006; Hartel and Pattison 1996), of many lower crustal terrains indicate that melt is extracted from metamorphosed mafic rocks, despite their comparatively low melt fraction. In addition, many granitic rocks are thought to be partly derived from melting of mafic source rocks (e.g., Chappell and White 2001).

Once melting and shearing-induced melt extraction has commenced in early melting lithologies (the pelite in our example), removal of melt creates a pressure differential that is relieved by migration of melt from adjacent meltbearing domains, provided that a continuous melt network is present. The limited degree of melt network connectivity and high viscosity of felsic melts restricts the length scale of this process, although the dimensions of this are not well constrained in the literature. Thus, in granulite facies terrains, there are many points from which melt can be extracted, so this process allows melt extraction from broad regions that can include relatively low melt domains. At temperatures slightly higher than the initial muscovite dehydration melting reactions, biotite dehydration melting commences, in both pelitic rocks and $\mathrm{K}$-altered mafic rocks. At this point, the $\mathrm{K}$-altered, biotitic mineralized volume within the mafic body in the example above would experience a higher degree of melting than the immediately surrounding unmineralized mafic rocks. It thus would become the locally dominant melt extraction pathway, allowing it to link in with the regional melt extraction network. Similarly, in intermediate to pelitic bulk compositions, potassic alteration causes a higher proportion of melt to be generated through biotite dehydration melting (Figs. 2 and 4). In this way, biotite alteration is also important for promoting preferential magma extraction from K-enriched crust. 
Implications of voluminous melting associated with potassic alteration

Metals and sulfur can escape through shear-related pathways with silicate melt, forming metal-enriched batches of magma in three ways. In combination, these three mechanisms cannot only lead to enrichment of gold, but also the range of other elements comprising the ore mineral assemblage, including sulfur. Firstly, sulfide minerals can partially dissolve in felsic melts, which are then locally sulfur-saturated. However, the solubility of sulfides and gold in felsic melts is low (e.g., Frank et al. 2002; Li and Ripley 2005; Liu et al. 2007), so only a trace fraction of the total ore mineral budget in any given metamorphosed deposit can be incorporated in this way. Although recently it has been found that the solubility of gold in reduced felsic melts (sulfide stability field) is directly dependant on $f \mathrm{~S}_{2}$, with higher $f \mathrm{~S}_{2}$ values corresponding to higher gold solubilities (up to 5,200 ppb Au; Jego et al. 2007), indicating that, under appropriate conditions, a significant proportion of $\mathrm{Au}$ can escape via this mechanism. Scheelite is highly soluble in felsic melts, with solubilities exceeding 1,000 ppm (Stemprok 1990), so any tungsten present can also be extracted by this mechanism.

Secondly, gold-bearing metal-sulfide-sulfosalt assemblages can partially melt (Tomkins et al. 2004a, b; Tomkins et al. 2007), allowing them to migrate with silicate magma as immiscible sulfide melt blebs during deformationinduced melt migration (Tomkins and Mavrogenes 2002, 2003). In summary, these authors suggested that because sulfide and silicate melts both respond to strain in the same way, by migrating down pressure gradients towards dilational domains, they migrate to the same structural sites. This process facilitates incorporation of sulfide melt within silicate melt that escapes the lower crust. The settling rate of gold-rich sulfide melts, of the same size as those found at the Challenger deposit, was found to be slower than typical ascent rates of felsic magmas (Tomkins and Mavrogenes 2003).

The above two mechanisms are not capable of removing all of the gold present in a deposit because (1) the local concentration of gold in deposits often far exceeds its solubility in felsic magma (e.g., the average grade of Challenger is $8.6 \mathrm{ppm}$ and locally exceeds $2000 \mathrm{ppm})$, and (2) not all of the gold melts because it is not all in chemical communication with enough of the sulfosalt phases required for 100\% melting (e.g., numerous gold deposits contain grains of gold chemically isolated within quartz veins). Instead, additional solid sulfide, oxide, and gold grains may be physically incorporated within, and carried along by, felsic magma. Physical incorporation can occur via entrainment of unmelted masses of sulfide- or oxidebearing residual rock, particularly in a diatexite migmatite, which then become xenoliths (cf. Clarke 2007). In addition, individual ore mineral grains can be entrained as melt migrates from the site of melting through migmatitic leucosomes and into a granitic accumulation. This physical entrainment has been demonstrated to occur with peritectic garnet (Stevens et al. 2007), which is has been found in many peraluminous granitic intrusions. By using the diameter of naturally occurring garnet xenocrysts in granite (e.g., Jung et al. 2000) and Stokes' Law, it is possible to evaluate the equivalent size of a pyrrhotite or gold grain that can be physically incorporated this way (one assumes that since the garnet is observed in the granite it cannot have settled out). Using a conservative garnet diameter of $5 \mathrm{~mm}$, density for granite of $2,750 \mathrm{~kg} \mathrm{~m}^{-3}$, and viscosity for granite of $10^{5} \mathrm{~Pa} \mathrm{~s}$ (Scaillet et al. 1998), we find that a garnet crystal of this size equates, in settling rate, to a pyrrhotite grain of $4.04 \mathrm{~mm}$ diameter or a gold grain of $1.35 \mathrm{~mm}$ diameter. Since these diameters are significantly larger than most sulfide or gold grains found in natural deposits, the conclusion is reached that these ore mineral grains can be physically entrained within magma escaping the lower crust.

At this point, it would be fair to ask why the Challenger deposit exists at all if it has undergone migmatization. Challenger consists of a series of three main narrow $(\sim 20 \mathrm{~m})$, shallowly plunging ore shoots within a $>300 \mathrm{~m}$ long As-rich trend that cuts across the dominant structural fabric. These ore shoots are structurally dilatant features relative to the more highly strained inter-ore shoot domains (Tomkins and Mavrogenes 2002). It is believed that the inter-ore shoot domains were part of the original mineralized body prior to peak metamorphism. As melting and deformation progressed, melt and metal may have been preferentially extracted from these inter-ore shoot domains, whereas the adjacent, comparatively dilational domains retained melt and metal or were perhaps even sites of some melt accumulation. This interpretation is consistent with the observation that leucosomes within the ore shoots display textures indicative of retrograde reaction between melt and peritectic phases, indicating melt preservation, as well as the presence of thick leucocratic accumulations. Given the relative volume of the inter-ore shoot domains, more metal may have been lost from the Challenger deposit than retained within it.

The metal and sulfur content of magmas escaping the lower crust depends on which extraction mechanisms are operating, the richness of the source, as well as magma migration dynamics, and thus may be locally highly variable. Mixing with sulfide-undersaturated magmas in shear zones would lead to dissolution of physically incorporated sulfides. Because most of the lower crust is relatively reduced (e.g., Spear 1993), including metamorphosed sulfide deposits (being pyrrhotite-rich at high 
temperatures), the resulting felsic magmas are reduced and relatively metal-enriched. The magmas do not need to be $\mathrm{K}_{2} \mathrm{O}$ saturated - for this to be the case, the melting reactions need to have quartz or plagioclase as the limiting reactants, which is unlikely when the intensity of alteration is mild, as seen in many orogenic gold deposits (in both of the modeled deposits, muscovite is a limiting reactant). The magmas may nevertheless be expected to be relatively potassic, as muscovite is usually the limiting reactant in most source regions. A further constraint is that migmatitic melts derived from partial melting of muscovite-rich quartzofeldspathic or pelitic compositions should be metaluminous to peraluminous.

The relative proportions of magmas sourced from mineralized and unmineralized rock will influence the metal content of a given body of felsic magma. K-enriched mineralized zones are only small, localized occurrences within broader regions that contain significant variability in fertility. Within any broader region undergoing high-grade metamorphism and partial melting, there will be numerous localities of preferential melt extraction, most of which will be unmineralized. However, the enormous volumes of felsic intrusions, and the proportion of melting of the lower crust implied by migmatite textures, require coalescence of magmas sourced from very large regions of lower crust. Potassic alteration-associated voluminous melting and strain partitioning-controlled melt extraction are therefore significant in that these raise the ratio of magma from metal-rich sources to that from low-metal sources. Ideal conditions for generation of metal-enriched crust-derived magmas are a combination of minimal wet melting and low degrees of dehydration melting in regions with a high proportion of zones with mineralized potassic alteration.

\section{Implications of preservation potential for crustal} metal recycling

The higher preservation potential of the deeper-formed orogenic gold deposits means that they are more likely than other deposit types to eventually be tectonically emplaced into a position where they can be metamorphosed at high $P-T$ conditions. Thus, more of the metals found in these deposits, $\mathrm{Au}, \mathrm{Ag}, \mathrm{As}, \mathrm{Bi}, \mathrm{Te}, \mathrm{Sb}$, and $\mathrm{W}$, can be recycled into the upper crust through partial melting of mineralized crust, than those associated with upper crustal ore deposits (mainly $\mathrm{Cu}$ and $\mathrm{Mo}$, but also $\mathrm{Au}, \mathrm{Ag}, \mathrm{Pb}, \mathrm{Zn}, \mathrm{Hg}$ from epithermal deposits). Metals from the upper crustal deposits are recycled via sedimentary basins, in which metals will be dispersed at background level concentrations. In some cases, metals in this setting can be concentrated again via formation of exhalative type ores, but this process mainly concentrates $\mathrm{Pb}, \mathrm{Zn}$, and $\mathrm{Ag}$ without formation of potassic alteration halos. When these basins undergo orogenesis, the exhalative deposits are not the focus of melt extraction, and metals are not preferentially extracted from any particular locality. This statement can be assessed by looking at the Broken Hill deposit in Australia, which was metamorphosed at granulite facies conditions. Well away from the mineralized zones at this locality, there has been widespread partial melting of pelitic to psammopelitic assemblages (e.g., White et al. 2004), but there is comparatively little silicate melting within the deposit. The implication of these arguments is that in the main, $\mathrm{Cu}$ and Mo need to be added to the crust from the mantle to form new ore deposits, whereas $\mathrm{Au}, \mathrm{Ag}, \mathrm{As}, \mathrm{Sb}, \mathrm{Bi}, \mathrm{Te}$, and $\mathrm{W}$ can be partly sourced from zones of enrichment in the crust.

These arguments allow an assessment of broad regions, which might help to distinguish those favorable for generation of intrusion-related ore systems. In tectonic settings where metamorphism results from heating from below, deep-crustal regions devolatilize early, possibly allowing formation of orogenic $\mathrm{Au}$ deposits at mid-crustal levels, which could be metamorphosed as the thermal pulse reaches the mid-crust (Stuwe 1998). However, the magnitude of this late thermal pulse is unlikely to be great enough to cause regional vapor-absent melting at mid-crustal levels. Crust-derived felsic magmas generated in this setting may instead be dominated by melt from metal-depleted lower crust.

For most types of potassic alteration-associated mineralization to undergo partial melting during regional metamorphism, they must go through a second cycle of tectonism. The mineralized protolith is therefore more likely to be relatively old crust due to the time needed for mineralized crust to form in one tectonic event, stabilize, and then become metamorphosed during a second tectonic event. Neoarchean crust, the mid-crustal levels of which generally contain a relatively high proportion of orogenic gold mineralization associated with potassic alteration, would be an ideal basement. The region surrounding the Challenger deposit is an example of such a basement, with numerous occurrences of gold anomalism reported within a broad region of granulite facies metamorphosed Neoarchean crust. In another example, generation of Mesozoic granitic magmas that host gold deposits in the North China craton (Zhou et al. 2002) arguably involved partial melting deeper within the Archean basement that they intrude. However, some younger crustal regions such as the Victorian Goldfields (Ordovician-Devonian), with numerous turbidite-hosted orogenic gold deposits, would be ideal for regional generation of metal-enriched felsic magmas. It may be that crust of this age underlies some of the younger mineral belts with intrusion-related gold systems.

Intrusion-related gold systems have been suggested by others to involve magmas of largely crustal derivation. 
These are associated with reduced alkalic to calc-alkalic, metaluminous to peraluminous intrusions (Lang and Baker 2001); compositions that are consistent with derivation, at least in part, from the altered crustal sources under discussion. These authors noted that despite uncertainties between and within provinces, most or all intrusion-related gold deposits formed above or within old, typically cratonic continental crust in a setting well removed, or most distal, from convergent margins active at the time of magmatism. We therefore suggest that preexisting gold mineralization within this old continental crust may be recycled through partial melting to become an important contributor to the metal budget of intrusion-related gold systems. Furthermore, given that mixing between mantle- and crust-derived magmas is possible in continental arcs and some complex island arcs (cf. Richards 2003), melting of old crustal gold mineralization may also contribute to the metal budget of gold-rich porphyry $\mathrm{Cu}$ deposits.

Acknowledgements We would like to thank John Mavrogenes for useful discussions relevant to this paper. Alberto Patiño Douce, D. Barrie Clark, and Jeremy Richards are thanked for their efforts in commenting on an earlier version of this manuscript. Two reviewers, Fritz Finger and Rolf Romer, as well as editor Larry Meinert, are thanked for their efforts. Funding was provided by a Monash Research Fellowship to A.G.T.

\section{References}

Antignano AI, Rushmer T, Daczko NR, Clark GL, Collins WJ, Kleppis KA (2001) Partial melting of a hornblende-biotiteclinozoisite bearing metadiorite: applications to the deep crust, Fiordland, New Zealand. Geol Soc Am, Abstracts with Programs $33: 211$

Baker T (2002) Emplacement depth and $\mathrm{CO}_{2}$-rich fluid inclusions in intrusion-related gold deposits. Econ Geol 97:1109-1115

Bierlein FP, Fuller T, Stuwe K, Arne DC, Keays RR (1998) Wallrock alteration associated with turbidite-hosted gold deposits. Examples from the Palaeozoic Lachlan Fold Belt in central Victoria, Australia. Ore Geol Rev 13:345-380

Brown M (1994) The generation, segregation, ascent and emplacement of granite magma: the migmatite-to-crustally-derived granite connection in thickened orogens. Earth Sci Rev 36:83130

Brown M, Solar GS (1998) Granite ascent and emplacement during contractional deformation in convergent orogens. J Struct Geol 20:1365-1393

Cerny P, Blevin PL, Cuney M (2005) Granite-related ore deposits. In: Hedenquist JW, Thompson JFH, Goldfarb RJ, Richards JP (eds) Economic geology 100th anniversary volume 1905-2005. Society of Economic Geologists (Publ.), Littleton, Colorado, USA, pp 251-298

Chappel BW, White AJR (2001) Two contrasting granite types: 25 years later. Aust J Earth Sci 48:489-499

Clarke DB (2007) Assimilation of xenocrysts in granitic magmas: principles, processes, proxies, and problems. Can Miner 45:5-30

Clemens JD, Vielzeuf D (1987) Constraints on melting and magma production in the crust. Earth Planet Sci Lett 86:287-306
Connolly JAD, Cesare B (1993) C-O-H-S fluid composition and oxygen fugacity in graphitic metapelites. J Met Geol 11:379-388

Cox FF, Sun SS, Etheridge MA, Wall VJ, Potter TF (1995) Structural and geochemical controls on the development of turbidite-hosted gold quartz vein deposits, Wattle Gully mine, central Victoria. Econ Geol 90:1722-1746

Elmer FL, White RW, Powell R (2006) Devolatilization of metabasic rocks during greenschist-amphibolite facies metamorphism. J Met Geol 24:497-513

Frank MR, Candela PA, Piccoli PM, Glascock MD (2002) Gold solubility, speciation, and partitioning as a function of $\mathrm{HCl}$ in the brine-silicate melt-metallic gold system at $800^{\circ} \mathrm{C}$ and $100 \mathrm{MPa}$. Geochim Cosmochim Acta 66:3719-3732

Garrido CJ, Bodinier JL, Burg JP, Zeilinger G, Hussain SS, Dawood H, Chaudhry MN, Gervilla F (2006) Petrogenesis of mafic garnet granulite in the lower crust of the Kohistan paleo-arc complex (northern Pakistan); implications for intra-crustal differentiation of island arcs and generation of continental crust. J Pet 47:1873-1914

Groves DI, Goldfarb RJ, Gebre-Mariam M, Hagemann SG, Robert F (1998) Orogenic gold deposits: a proposed classification in the context of their crustal distribution and relationship to other gold deposit types. Ore Geol Rev 13:7-27

Groves DI, Kondie KC, Goldfarb RJ, Hronsky JMA, Vielreicher RM (2005) Secular changes in global tectonic processes and their influence on the temporal distribution of gold-bearing mineral deposits. Econ Geol 100:203-224

Hartel THD, Pattison DRM (1996) Genesis of the Kapuskasing (Ontario) migmatitic mafic granulites by dehydration melting of amphibolite: the importance of quartz to reaction progress. J Met Geol 14:591-611

Hedenquist JW, Lowenstern JB (1994) The role of magmas in the formation of hydrothermal ore deposits. Nature 370:519-527

Holland TJB, Powell R (1998) An internally consistent thermodynamic dataset for phases of petrological interest. J Met Geol 16:309-344

Jego S, Pichavant M, Mavrogenes JA (2007) Experimental study of the behaviour of gold in calc-alkaline arc magmas: demonstration of the effect of sulphur and geological implications on the formation of gold deposits. AGU Fall Meeting, San Francisco, Abs\# V41D-0819

Jung S, Hoernes S, Mezger K (2000) Geochronology and petrogenesis of Pan-African, syn-tectonic, S-type and post-tectonic A-type granite Namibia: products of melting of crustal sources, fractional crystallization and wall rock entrainment. Lithos 50: 259-287

Krauskopf KB (1967) Source rocks for metal bearing fluids. New york, Holt, Rinehart and Winston, 1-33 p

Lang JL, Baker T (2001) Intrusion-related gold systems: the present level of understanding. Miner Depos 36:477-489

Li C, Ripley EM (2005) Empirical equations to predict the sulfur content of mafic magmas at sulfide saturation and applications to magmatic sulfide deposits. Miner Depos 40:218-230

Liu Y, Samaha N-T, Baker DR (2007) Sulfur concentration at sulfide saturation (SCSS) in magmatic silicate melts. Geochim Cosmochim Acta 71:1783-1799

Mancktelow NS (2002) Finite-element modelling of shear zone development in viscoelastic materials and its implications for localisation of partial melting. J Struct Geol 24:1045-1053

Mancktelow NS (2006) How ductile are ductile shear zones? Geology 34:345-348

McFarlane CRM (2006) Palaeoproterozoic evolution of the Challenger $\mathrm{Au}$ deposit, South Australia, from monazite geochronology. J Met Geol 24:75-87

McFarlane CRM, Mavrogenes JA, Tomkins AG (2007) Recognizing hydrothermal alteration through a granulite facies metamorphic overprint at the Challenger Au deposit, South Australia. Chem Geol 243:64-89 
Mungall JE (2002) Roasting the mantle: slab melting and the genesis of major $\mathrm{Au}$ and Au-rich $\mathrm{Cu}$ deposits. Geology 30:915-918

Richards JP (2003) Tectono-magmatic precursors for porphyry $\mathrm{Cu}-$ (Mo-Au) deposit formation. Econ Geol 98:1515-1533

Ridley JR, Groves DI, Knight JT (2000) Gold deposits in amphibolite and granulite facies terranes of the Archean Yilgarn craton, Western Australia: evidence and implications for synmetamorphic mineralization. Rev Econ Geol 11:265-290

Rosenberg CL, Handy MR (2005) Experimental deformation of partially melted granite revisited: implications for the continental crust. J Met Geol 23:19-28

Rutherford L, Hand M, Mawby J (2006) Delamarian-aged metamorphism in the southern Curnamona Province, Australia: implications for the evolution of the Mesoproterozoic Olarian Orogeny. Terra Nova 18:138-146

Scaillet B, Holtz F, Pichavant M (1998) Phase equilibrium constraints on the viscosity of silicic magmas: 1 . Volcanic-plutonic comparison. J Geophys Res 103:27257-27266

Seedorf E, Dilles JH, Proffett JM Jr., Einaudi MT, Zurcher L, Stavast WJA, Johnson DA, Barton MD (2005) Porphyry deposits: characteristics and origin of hypogene features. In: Hedenquist JW, Thompson JFH, Goldfarb RJ, Richards JP (eds) Economic geology 100th anniversary volume 1905-2005. Society of Economic Geologists (Publ.), Littleton, Colorado, USA, pp 251-298

Sillitoe RH (1972) Relation of metal provinces in western America to subduction of oceanic lithosphere. Geol Soc Am Bull 83:813-818

Sillitoe RH (1997) Characteristics and controls of the largest porphyry copper-gold and epithermal gold deposits in the circum-Pacific region. Aust J Earth Sci 44:373-388

Spear FS (1993) Metamorphic phase equilibria and pressure-temperaturetime paths. Mineralogical Society of America, Washington, p 799

Stemprok M (1990) Solubility of tin, tungsten and molybdenum oxides in felsic magmas. Miner Deposita 25:205-212

Stevens G, Villaros A, Moyen J-F (2007) Selective peritectic garnet entrainment as the origin of geochemical diversity in S-type granites. Geology 35:9-12

Stuwe K (1998) Tectonic controls on the timing relationships of metamorphism, fluid production and gold-bearing quartz vein emplacement. Ore Geol Rev 13:219-228
Thompson AB (1996) Fertility of crustal rocks during anatexis. Trans Royal Soc Edinburgh-Earth Sci 87:1-10

Tomkins AG, Mavrogenes JA (2002) Mobilization of gold as a polymetallic melt during pelite anatexis at the Challenger deposit, South Australia: a metamorphosed Archean gold deposit. Econ Geol 97:1249-1271

Tomkins AG, Mavrogenes JA (2003) Generation of metal-rich felsic magmas during crustal anatexis. Geology 31:765-768

Tomkins AG, Dunlap WJ, Mavrogenes JA (2004a) Geochronological constraints on the polymetamorphic evolution of the granulitehosted Challenger gold deposit: implications for assembly of the northwest Gawler Craton. Aust J Earth Sci 51:1-14

Tomkins AG, Pattison DRM, Zaleski E (2004b) The Hemlo gold deposit, Ontario: an example of melting and mobilization of a precious metal-sulfosalt assemblage during amphibolite facies metamorphism and deformation. Econ Geol 99:1063-1084

Tomkins AG, Pattison DRM, Frost BR (2007) On the initiation of metamorphic sulfide anatexis. J Pet 48:511-535

White RW, Powell R (2002) Melt loss and preservation of granulite facies mineral assemblages. J Met Geol 20:621-632

White RW, Powell R, Holland TJB (2001) Calculation of partial melting equilibria in the system $\mathrm{Na}_{2} \mathrm{O}-\mathrm{CaO}-\mathrm{K}_{2} \mathrm{O}-\mathrm{FeO}-\mathrm{MgO}-$ $\mathrm{Al}_{2} \mathrm{O}_{3}-\mathrm{SiO}_{2}-\mathrm{H}_{2} \mathrm{O}$ (NCKFMASH). J Met Geol 19:139-153

White RW, Powell R, Clarke GL (2002) The interpretation of reaction textures in Fe-rich metapelitic granulites of the Musgrave Block, central Australia: constraints from mineral equilibria calculations in the system $\mathrm{K}_{2} \mathrm{O}-\mathrm{FeO}-\mathrm{MgO}-\mathrm{Al}_{2} \mathrm{O}_{3}-\mathrm{SiO}_{2}-\mathrm{H}_{2} \mathrm{O}-\mathrm{TiO}_{2}-\mathrm{Fe}_{2} \mathrm{O}_{3}$. J Pet 20:41-55

White R, Powell R, Phillips GN (2003) A mineral equilibria study of the hydrothermal alteration in mafic greenschist facies rocks at Kalgoorlie, Western Australia. J Met Geol 21:455-468

White RW, Powell R, Halpin JA (2004) Spatially focused melt formation in aluminous metapelites from Broken Hill, Australia. J Met Geol 22:825-845

Wilde AR, Bierlein FP, Pawlitschek M (2004) Lithogeochemistry of orogenic gold deposits in Victoria, SE Australia: a preliminary assessment for undercover exploration. J Geochem Explor 84:35-50

Zhou T, Goldfarb RJ, Phillips GN (2002) Tectonics and distribution of gold deposits in China—a review. Miner Depos 37:249-282 